Published in final edited form as:

Appl Energy. 2014 September 1; 128: 284-295. doi:10.1016/j.apenergy.2014.04.072.

\title{
Evaluating the impacts of new walking and cycling infrastructure on carbon dioxide emissions from motorized travel: a controlled longitudinal study
}

\author{
Christian Brand, DPhil ${ }^{1}$, Anna Goodman, $\mathrm{PhD}^{2}$, and David Ogilvie, $\mathrm{PhD}^{3}$ on behalf of the \\ iConnect consortium \\ ${ }^{1}$ Environmental Change Institute, University of Oxford, Oxford, United Kingdom \\ ${ }^{2}$ Faculty of Epidemiology and Population Health, London School of Hygiene and Tropical \\ Medicine, London, UK (Anna.Goodman@Ishtm.ac.uk) \\ ${ }^{3}$ Medical Research Council Epidemiology Unit and UKCRC Centre for Diet and Activity Research \\ (CEDAR), University of Cambridge, Cambridge, UK (David.Ogilvie@mrc-epid.cam.ac.uk)
}

\begin{abstract}
Walking and cycling is widely assumed to substitute for at least some motorized travel and thereby reduce energy use and carbon dioxide $\left(\mathrm{CO}_{2}\right)$ emissions. While the evidence suggests that a supportive built environment may be needed to promote walking and cycling, it is unclear whether and how interventions in the built environment that attract walkers and cyclists may reduce transport $\mathrm{CO}_{2}$ emissions. Our aim was therefore to evaluate the effects of providing new infrastructure for walking and cycling on $\mathrm{CO}_{2}$ emissions from motorised travel.

A cohort of 1849 adults completed questionnaires at baseline (2010) and one-year follow-up (2011), before and after the construction of new high-quality routes provided as part of the Sustrans Connect2 programme in three UK municipalities. A second cohort of 1510 adults completed questionnaires at baseline and two-year follow-up (2012). The participants reported their past-week travel behaviour and car characteristics from which $\mathrm{CO}_{2}$ emissions by mode and purpose were derived using methods described previously. A set of exposure measures of proximity to and use of the new routes were derived.
\end{abstract}

Overall transport $\mathrm{CO}_{2}$ emissions decreased slightly over the study period, consistent with a secular trend in the case study regions. As found previously the new infrastructure was well used at oneand two-year follow-up, and was associated with population-level increases in walking, cycling and physical activity at two-year follow-up. However, these effects did not translate into sizeable $\mathrm{CO}_{2}$ effects as neither living near the infrastructure nor using it predicted changes in $\mathrm{CO}_{2}$ emissions from motorised travel, either overall or disaggregated by journey purpose. This lack of a discernible effect on travel $\mathrm{CO}_{2}$ emissions are consistent with an interpretation that some of those

Corresponding Author: Christian Brand, Environmental Change Institute, University of Oxford, OX1 3QY, United Kingdom. Tel: +44(0)1865 285527; Fax: +44(0)1865 275885; christian.brand@ouce.ox.ac.uk.

AUTHORS' CONTRIBUTIONS

DO leads the iConnect work package that includes this survey, and DO and CB participated in the design of the survey. CB and AG defined the research question addressed in this paper, with $\mathrm{CB}$ calculating carbon emissions and AG performing statistical analyses. CB drafted the manuscript, and AG and DO revised it critically for important intellectual content. All authors read and approved the final manuscript. 
living nearer the infrastructure may simply have changed where they walked or cycled, while others may have walked or cycled more but few, if any, may have substituted active for motorised modes of travel as a result of the interventions.

While the findings to date cannot exclude the possibility of small effects of the new routes on $\mathrm{CO}_{2}$ emissions, a more comprehensive approach of a higher 'dosage' of active travel promotion linked with policies targeted at mode shift away from private motorized transport (such as urban car restraint and parking pricing, car sharing/pooling for travel to work, integrating bike sharing into public transport system) may be needed to achieve the substantial $\mathrm{CO}_{2}$ savings needed to meet climate change mitigation and energy security goals.

\section{Keywords}

transport; $\mathrm{CO}_{2}$ emissions; walking and cycling; infrastructure; longitudinal analysis; impact evaluation

\section{INTRODUCTION}

Passenger transport has been a priority sector for reducing its significant impacts of fossil energy use and associated greenhouse gas emissions for many years. Replacing motorised travel with low carbon modes such as walking and cycling is increasingly recognised as important in low carbon and energy demand reduction strategies [1-7]. In many countries, the majority of trips made by car are short-distance journeys to work, education or shopping [6, 8]. In the United Kingdom (UK), for instance, about one fifth of carbon dioxide $\left(\mathrm{CO}_{2}\right)$ emissions ${ }^{1}$ and transport energy use come from car journeys of less than 8 kilometres which could be made by foot or bicycle [10,11]. Walking and cycling for transport ('active travel') are widely assumed to substitute for at least some motorized travel and thereby reduce $\mathrm{CO}_{2}$ emissions [3, 12-16]. This assumption is supported by the findings that bicycle access is negatively correlated with $\mathrm{CO}_{2}$ emissions from motorized travel [17], that energy expenditure from walking is negatively correlated with fossil fuel use from car driving [18] and that individuals in more 'walkable' neighbourhoods make more walking trips and travel fewer vehicle kilometres [19]. For these reasons, promoting active travel has been discussed as one area with potential climate change, energy and health 'co-benefits' [4, 20, 21].

While it has been argued that a supportive built environment may be needed to promote and sustain increases in population physical activity [22,23], a number of reviews have highlighted the lack of controlled, longitudinal studies evaluating the effects of new infrastructure on walking and cycling [24-27]. More recently we have shown that new highquality walking and cycling routes in the UK were well-used at both one- and two-year follow-up [28] and were associated with population-level increases in walking, cycling and physical activity at two-year follow-up [29]. In all these studies, however, it was unclear whether increased activity and/or infrastructure use reflected (i) the generation of new walking and cycling trips, (ii) the substitution of trips previously made by motorized modes

\footnotetext{
${ }^{1}$ For land-based passenger transport, $\mathrm{CO}_{2}$ is by far the most important greenhouse gas, comprising approximately $99 \%$ of direct greenhouse gas emissions [9].
} 
of transport, or (iii) the displacement of walking and cycling trips formerly conducted elsewhere. Reductions in transport $\mathrm{CO}_{2}$ emissions would only be expected if motorised trips were substituted (scenario ii) or if, for example, recreational walking trips at locations formerly reached by car [14] were now conducted closer to home (a special case of scenario iii). We are not aware of any controlled, longitudinal studies evaluating the effects of new infrastructure on $\mathrm{CO}_{2}$ emissions from (displaced) motorized travel.

This paper therefore sought to extend our previous evaluation of high-quality, traffic-free walking and cycling routes $[28,29]$ by examining impacts on $\mathrm{CO}_{2}$ emissions from motorized travel. Specifically, given that the routes were well used and associated with population-level increases in walking, cycling and physical activity (after two years), we aimed to explore the extent to which proximity to and use of the routes predicted decreases in transport $\mathrm{CO}_{2}$ emissions over one- and two-year follow-up, and whether any associations varied across different journey purposes. In other words, we aimed to answer the questions: do people living closer to the new routes or use them have lower/higher $\mathrm{CO}_{2}$ emissions from motorised travel than people living further away or do not use them?

\section{METHODS}

\subsection{Intervention, study sites and sample}

Led by the sustainable transport charity Sustrans, the Connect 2 initiative is building or improving walking and cycling routes at multiple sites across the United Kingdom (map in Appendix A). Each Connect2 site comprises one flagship engineering project (the 'core' project) plus new or improved feeder routes (the 'greater' project) (Figure 1). These projects are tailored to individual sites but all embody a desire to create new routes for "everyday, local journeys by foot or by bike" [30].

The independent iConnect research consortium (www.iconnect.ac.uk) was established to evaluate the travel, physical activity and $\mathrm{CO}_{2}$ emissions impacts of Connect2 [31,32]. As previously described in detail [31], three Connect2 projects were selected for detailed study according to criteria including urban/rural location, relative size, implementation timetable, likelihood of measurable population impact and heterogeneity of overall mix of sites. These core study sites were: Cardiff/Penarth, where a traffic-free bridge was built over Cardiff Bay to Penarth; Kenilworth, where a traffic-free bridge was built over a busy trunk road; and Southampton, where an informal riverside footpath was turned into a boardwalk (see also [31]). None of these projects had been implemented during the baseline survey in April 2010. At one-year follow-up, most feeder routes had been upgraded and the core projects had opened in Southampton and Cardiff in July 2010. At two-year follow-up, almost all feeder routes were complete and the core Kenilworth project had opened in September 2011.

The baseline survey used the edited electoral register to select 22,500 adults living within a $5 \mathrm{~km}$ road network distance of the core Connect 2 projects, using a stratified (by distance), randomised sampling approach [14, 17, 31]. In April 2010 potential participants were posted a survey pack, which 3516 individuals returned. These 3516 individuals were posted followup surveys in April 2011 and 2012; 1885 responded in 2011 and 1548 in 2012. After excluding individuals who had moved house, the one-year follow-up study population 
cohort comprised 1849 participants (53\% retention rate, $8 \%$ of the population originally approached) and the two-year study population cohort comprised 1510 (43\% retention, 7\% of the original population). The University of Southampton Research Ethics Committee granted ethical approval (CEE200809-15).

\section{$2.2 \mathrm{CO}_{2}$ emissions calculations}

The $\mathrm{CO}_{2}$ emissions ${ }^{2}$ calculation methods for motorized travel modes have been published previously in $[14,17]$. In brief, weekly travel activity was measured using a seven-day recall instrument [31] covering five journey purposes: 'commuting for work', 'travel for education', 'travel in the course of business', 'shopping or personal business', and 'social, visiting friends or other leisure activities'. For each journey purpose, participants recalled the total number of trips made, distance and time spent travelling by seven modes: 'walking', 'cycling', 'car/van as driver', 'car/van as passenger', 'bus', 'train' and 'other' (taxi, motorcycle, etc.). From this information, mean speeds and mean trip distances were derived for each journey purpose. If only distance or time was reported then the counterpart was imputed using the mean observed speed for each mode and journey purpose.

As fully described previously $[14,17]$, we used these travel activity data to derive $\mathrm{CO}_{2}$ emissions, with different methods for car and non-car modes. For cars and vans, the selfreported data on weekly travel activity, vehicle fuel, size and age allowed for the use of a disaggregate method including the estimation of 'hot' $\mathrm{CO}_{2}$ emissions, which are a function of distance travelled, mean speed, fuel type, size and age (calculated separately in 2010, 2011 and 2012 to reflect the ageing vehicle fleet), and 'cold start' $\mathrm{CO}_{2}$ emissions (excess emissions during the warm-up phase). Emissions from travel 'commuting for work' and 'travel for education' were combined into a 'commuting' category. As we lacked detailed data on car-sharing we modelled $\mathrm{CO}_{2}$ in two ways, (a) one dividing emissions from car travel between passengers and drivers and (b) one assigning all emissions to the driver. The substantive findings were generally identical and we therefore report in the main text the results for $\mathrm{CO}_{2}$ shared between drivers and passengers. For travel by bus, train and 'other' modes, self-reported data on distance travelled by trip purpose were multiplied by modespecific, average $\mathrm{CO}_{2}$ emissions factors obtained from the UK Department of Environment, Food and Rural Affairs [34].

\subsection{Use of the Connect2 infrastructure}

At each follow-up, participants were given a description of their local Connect2 project and asked "Do you use the [Connect2 infrastructure]?" (yes/no). Participants reporting using Connect 2 were then asked whether they (a) walked or (b) cycled on Connect 2 for any of the five 'transport' journey purposes given above or for 'recreation, health or fitness'. We used these to create a measure of any Connect 2 use for transport; any Connect 2 use for commuting/business purposes; or any Connect2 use for shopping/social purposes. We also counted the number of transport journeys they reported.

\footnotetext{
${ }^{2} \mathrm{We}$ used $\mathrm{CO}_{2}$ and not $\mathrm{CO}_{2}$ equivalent $\left(\mathrm{CO}_{2} \mathrm{e}\right)$ as our primary outcome measure because (a) $\mathrm{CO}_{2}$ emissions dominate direct $\mathrm{CO}_{2} \mathrm{e}$ emissions from surface passenger transport, making up approximately $99 \%$ of direct $\mathrm{CO}_{2} \mathrm{e}$ [9], and (b) vehicle emissions rates for the non- $\mathrm{CO}_{2}$ greenhouse gases methane $\left(\mathrm{CH}_{4}\right)$ and nitrous oxide $\left(\mathrm{N}_{2} \mathrm{O}\right)$ are much less certain than for $\mathrm{CO}_{2}$ [33], thus potentially introducing uncertainty in outcome measures for little added benefit.
} 


\subsection{Baseline characteristics of the participants}

Table 1 presents the baseline characteristics examined as predictors of transport $\mathrm{CO}_{2}$ emissions. Most characteristics were based on self-reported measures, including demographic and socio-economic variables and measures of access to cars and bicycles. 'Total past-week walking and cycling' was derived by summing the four constituent times of self-reported walking and cycling for both transport and recreation. ${ }^{3}$ Participants also provided self-reported height and weight, from which we calculated body mass index $\left(\mathrm{kg} / \mathrm{m}^{2}\right)$. Applying standard cut-offs, we used BMI to classify participants as being of normal weight $(\mathrm{BMI}<25)$, overweight $(25 \$ \mathrm{BMI}<30)$ or obese $(30 \triangleleft \mathrm{BMI})$. Site and urban/ rural status were derived by matching home postcodes to Lower Super Output Areas, using mid-2010 population estimates for the latter [36]).

\subsection{Exposure to the intervention}

Given that our main aim was to answer the question whether people living closer to the new routes have lower $\mathrm{CO}_{2}$ emissions from motorised travel than people living further away, we developed a hierarchical set of proximity measures. The primary measure of exposure was proximity to Connect2 [31], operationalized as the distance from the weighted population centroid of the unit postcode ${ }^{4}$ containing the participant's home to the nearest access point to a completed section of the 'greater' Connect2 project (calculated separately in 2011 and 2012 to reflect ongoing upgrades: Figure 1). Distance was calculated in ArcGIS 9 using the Ordnance Survey's Integrated Transport Network and Urban Path layers, which include the road network plus traffic-free or informal paths. For ease of interpretation, we reverse coded distance from the intervention to generate a measure of proximity - i.e. treating those living within $1 \mathrm{~km}$ as having a higher proximity than those living over $4 \mathrm{~km}$ away (Table 1 ).

Secondary exposure measures were: distance to the 'core' (flagship) Connect2 project (e.g. the 'core' infrastructure element of the Kenilworth scheme illustrated in Figure 2); using Connect 2 for any purpose ('general' use); and using Connect 2 for the specific mode and purpose in question (i.e. using Connect2 for walking for transport as the exposure when change in past-week time spent walking for transport was the outcome).

\subsection{Analysis}

Missing data ranged from $0 \%$ to $1.2 \%$ across exposure and outcome variables, and from 0 to $8.1 \%$ among covariates. These data were imputed using multiple imputation by chained equations (five imputations) under an assumption of missing at random. To allow for potential correlations between participants living in the same neighbourhood, robust standard errors were used clustered by Lower Super Output Area (average population 1500).

Effects on $\mathrm{CO}_{2}$ emissions were examined by calculating change in past-week $\mathrm{CO}_{2}$ emissions for all travel; for commuting and travel in the course of business only; and for travel for shopping, personal business, social and leisure only. Linear regression was used to examine

\footnotetext{
${ }^{3}$ Past-week recreational walking and cycling were measured by adapting the short form of the International Physical Activity Questionnaire (IPAQ) [35].

${ }^{4}$ In the UK residential unit postcodes (such as 'SO17 1BJ') typically relate to around 15 residential addresses and 36 people (based on the average household size of 2.4) [37].
} 
how the different exposure measures predicted these three change scores. Multivariable models were initially adjusted for age, sex and site, and then adjusted for all baseline demographic, socio-economic, geographic, and health characteristics (entered categorically, as in Table 1).

Statistical analyses were conducted in 2012 and 2013 using Stata 11.

\section{RESULTS}

\subsection{Characteristics of study participants}

The one- and two-year study samples had very similar characteristics (Table 1), and all findings were unchanged in sensitivity analyses restricted to those who provided data at both time points. Comparisons of the study population with the general population (given in Appendix B) showed that participants included fewer young adults than the general population (e.g. $7 \%$ in the two-year sample vs. $26 \%$ of adults locally) and were also somewhat healthier, better-educated and less likely to have children. Otherwise the study population appeared to be broadly representative in its demographic, socio-economic, travel and activity-related characteristics.

\subsection{Trends in levels and sources of $\mathrm{CO}_{2}$ emissions from motorised travel}

Mean $\mathrm{CO}_{2}$ emissions from all motorised surface passenger travel decreased slightly over the study time horizon. At one-year follow-up, mean $\mathrm{CO}_{2}$ emissions were 31 kilograms of $\mathrm{CO}_{2}$ $\left(\mathrm{kgCO}_{2}\right)$ per person per week, an estimated $1.7 \mathrm{kgCO}_{2}$ lower than at baseline $(95 \% \mathrm{CI} 0.4$, 2.9). At two-year follow-up, mean emissions were $3.0 \mathrm{kgCO}_{2}$ lower than baseline (1.6, 4.3). These mean levels correspond to about 1.5 to 1.6 tonnes of $\mathrm{CO}_{2}\left(\mathrm{tCO}_{2}\right)$ per person per year, 5 figures comparable to government estimates of per capita road transport emissions in Great Britain $[38,39] .{ }^{6}$ The proportion of transport emissions attributable to car travel decreased from $89 \%$ (baseline) to $88 \%$ (one-year follow-up) and 86\% (two-year follow-up), with the shortfall being made up by other public and private motorised travel. Further details on raw levels and changes in $\mathrm{CO}_{2}$ emissions by journey purpose can be found in the Appendix $\mathrm{C}$.

\subsection{Effect of Connect2 exposure on $\mathrm{CO}_{2}$ emissions from motorized travel}

Table 2 provides evidence as to whether the changes in $\mathrm{CO}_{2}$ emissions described above were associated with distance from or use of Connect2. For illustration, Figure 3 depicts this information for changes in total $\mathrm{CO}_{2}$ emissions at two-year follow-up with additional subdivision of some exposure categories (one-year follow-up results are illustrated in Appendix C). Overall we could not detect any significant effects of either use or proximity on $\mathrm{CO}_{2}$ emissions, regardless of whether these were examined overall or disaggregated by journey purpose ('commuting' or 'social/leisure'). Specifically, there was no evidence that distance from the 'greater' Connect2 projects predicted changes in total $\mathrm{CO}_{2}$ emissions (all p $>0.36$ for heterogeneity), and visual inspection did not indicate any consistent sense of non-

\footnotetext{
${ }^{5}$ We multiplied the weekly total by 47 (not 52), thus discounting 5 weeks of 'time away from home' (e.g. school holidays, public holidays). This was deemed appropriate since the measurement week fell outside those periods.

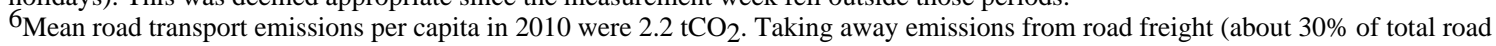
transport emissions) we arrive at $1.54 \mathrm{tCO}_{2}$ per capita.
} 
significant trends. There was likewise no evidence of an association when using distance from the 'core' Connect 2 project (all $\mathrm{p}>0.17$ ) or Connect 2 use (all $\mathrm{p}>0.05$, most $\mathrm{p}>0.2$ : see Table 2) as the exposure, or of a difference between use of the more-complete projects at Cardiff and Southampton and that of the less-complete project at Kenilworth (data not shown). Finally, there was no convincing evidence of differential effects across subpopulations in tests for interactions between Connect2 exposure and pre-specified individual and household characteristics.

In interpreting these findings it should be noted that the confidence intervals in Table 2 are comparatively wide, due to the high variability in $\mathrm{CO}_{2}$ emissions. This in turn reduced our statistical power to detect effects. To explore this issue further, post-hoc power calculations were performed using the observed number of individuals in different exposure categories and the observed standard deviations in change scores (see Appendix D). These calculations indicated that when comparing participants living $<2 \mathrm{~km}$ versus $\geq 2 \mathrm{~km}$ from greater Connect2, this study had $80 \%$ power to detect net changes between groups of 6-7 $\mathrm{kgCO}_{2} /$ week in total transport $\mathrm{CO}_{2}$ emissions. These thresholds were very similar when comparing Connect2 users with non-users.

\section{DISCUSSION}

\subsection{Key findings}

Overall, we found a small but significant decrease in mean population-level emissions over the study time horizon. We believe that this reflects a secular trend in the case study regions where fuel consumption [40] and $\mathrm{CO}_{2}$ emissions [41] from land surface passenger transport have decreased by similar rates during the time period. ${ }^{7}$ This may largely be due to (a) the effect of the recession and increases in private motoring costs and rail ticket fares on personal mobility $[9,42]$ and (b) a significant decrease in average new car $\mathrm{CO}_{2}$ emissions [43].

Against the background of this overall decreasing trend in emissions, we found no statistically significant evidence that living near Connect 2 or using Connect 2 predicted changes in $\mathrm{CO}_{2}$ emissions from motorised travel at one- and two-year follow-ups. This was true across aggregated and disaggregated outcome measures, and with respect to both the primary exposure measure (distance from the infrastructure) and several secondary measures (e.g. infrastructure use).

This lack of a discernible effect on $\mathrm{CO}_{2}$ emissions may at first be surprising given our previous findings that the new infrastructures were well-used at both one- and two-year follow-up [28] and were associated with population-level increases in walking, cycling and physical activity at two-year follow-up [29]. However, it is perhaps less surprising given the observation that our participants used Connect 2 more for recreational than for transport purposes, and more for walking than for cycling - neither of which tends to substitute for motorised travel on the longer (>8 kilometres) journeys that are responsible for around $80 \%$

\footnotetext{
${ }^{7}$ The latest local and regional data available to us, published in July 2013, are up to the year 2011 only. However, the trends on road transport fuel consumption and $\mathrm{CO}_{2}$ emissions have been downward since 2008 .
} 
of $\mathrm{CO}_{2}$ emissions from passenger transport $[6,10]$. Moreover, we have previously shown that the effects of Connect 2 upon walking and cycling were greatest among participants with no household car available to them [28], who may therefore have had less potential to reduce their emissions from motorised modes. Our findings are therefore consistent with an interpretation that the overall increase in walking and cycling attributable to Connect 2 may have been brought about more by generating new trips than by prompting a modal shift from motorised to non-motorised travel modes.

In interpreting these findings it is worth reflecting on this study's statistical power to detect changes in $\mathrm{CO}_{2}$ emissions. As shown in the post-hoc power calculations (Appendix D) this study had $80 \%$ power to detect differences of 6-7 $\mathrm{kgCO}_{2} /$ person/week or more in contrasts by distance ('live $<2 \mathrm{~km}$ ', 'live $>=2 \mathrm{~km}$ ') or Connect2 use ('yes', 'no'). This is comparable to a change in distance travelled by an average UK car (emitting $0.18 \mathrm{kgCO}_{2} / \mathrm{km} \mathrm{[43])} \mathrm{of} \mathrm{about}$ $36 \mathrm{~km}$ per week, which is comparable to the average distance travelled by car per day [9]. Similarly, it equates to about two-fifths the size of the difference between emissions from residents with no car available vs. those with at least one car available, or half the difference between those with at least one car available vs. those with two cars available to them ( 9 vs. 28 vs $42 \mathrm{kgCO}_{2}$ /week in the baseline sample as shown in [17]). The study was therefore able to detect relatively moderate differences in travel $\mathrm{CO}_{2}$ emissions, but lacking the power to detect smaller changes.

\subsection{Strengths and limitations}

The main strengths of this study include its cohort design, population-based sampling and use of a graded measure of exposure to enable controlled comparisons within the local populations. These represent important methodological advances on most previous studies on active travel and mode share (as potential precursors of $\mathrm{CO}_{2}$ emissions) which used repeat cross-sectional designs [44-46], only sampled infrastructure users [47] or used control groups which were not comparable at baseline [48]. Crucially, no previous study of this kind has estimated the effects on $\mathrm{CO}_{2}$ emissions. These study strengths allowed the examination of substantive questions such as those regarding the effects on $\mathrm{CO}_{2}$ emissions from motorised travel by journey purpose and transport mode. The approach has therefore the potential to be used by other researchers attempting to design and execute $\mathrm{CO}_{2}$ evaluations of complex infrastructural interventions in diverse contexts and circumstances.

Nevertheless, this study had several key limitations. Although the study sought to minimize measurement error by using seven-day recall instruments appropriate to the specific outcomes under investigation, the $\mathrm{CO}_{2}$ emissions outcomes still had high standard deviations (mainly due to social variability) and this reduced statistical power. The study was therefore able to detect relatively moderate changes in $\mathrm{CO}_{2}$ emissions, but lacked the power to detect smaller changes. Future evaluative research may address this limitation of small effect sizes by increasing the sample size and/or focussing solely on short trips below 8 kilometres where we would expect lower variability in the main outcomes. A second key limitation is the potential for selection bias: given the relatively low response rate, the study population cannot be assumed to be representative. Yet although older than the general population on average, participants generally appeared fairly similar in their demographic, 
socio-economic and travel-related characteristics (Appendix B). Moreover, we know of no reason to expect bias in the pattern of associations and, in particular, no reason to expect differential biases with respect to the primary exposure measure of distance from the intervention.

\section{CONCLUSIONS}

This paper set out to evaluate the population-wide impacts of new high-quality walking and cycling infrastructure in the $\mathrm{UK}$ on $\mathrm{CO}_{2}$ emissions from motorized travel. While the new routes attracted walkers and cyclists [28] and were associated with population-level increases in walking, cycling and physical activity [29], there was no evidence that this success translated into sizeable decreases in $\mathrm{CO}_{2}$ emissions from motorised travel across the study population. However, the findings to date cannot exclude the possibility of small effects of the new routes on $\mathrm{CO}_{2}$ emissions that this study lacked the power to detect. Further research would be needed to detect small effect sizes, most likely by increasing the sample size due to the often observed high variability of $\mathrm{CO}_{2}$ emissions from personal transport [17].

In the context of energy and climate policy, a more comprehensive approach of higher 'doses' of infrastructural interventions of the kind studied here, linked with ambitious active travel promotion and policies targeted at mode shift away from private motorized transport (e.g. $\mathrm{CO}_{2}$-graded car pricing at point of use, car restraint and parking pricing in urban areas, commuter car sharing, Park-and-Bike) may be required to achieve the substantial carbon savings needed to meet climate change mitigation and energy security goals.

\section{ACKNOWLEDGEMENTS}

This paper was written on behalf of the iConnect consortium (www.iconnect.ac.uk; Christian Brand, Fiona Bull, Ashley Cooper, Andy Day, Nanette Mutrie, David Ogilvie, Jane Powell, John Preston and Harry Rutter). The iConnect consortium is funded by the Engineering and Physical Sciences Research Council (grant reference EP/ G00059X/1). CB is also supported by the UK Energy Research Centre, part of the Research Councils UK Energy Research Programme. AG contributed to this work while funded by a National Institute of Health Research (NIHR) post-doctoral fellowship. DO is also supported by the Medical Research Council (Unit Programme number MC_UU_12015/6) and the Centre for Diet and Activity Research (CEDAR), a UKCRC Public Health Research Centre of Excellence. Funding from the British Heart Foundation, Economic and Social Research Council, Medical Research Council, NIHR and Wellcome Trust, under the auspices of the UK Clinical Research Collaboration, is gratefully acknowledged. The views in this publication are those of the authors and do not necessarily reflect those of the funders. We thank the study participants for their cooperation, the study team led by Karen Ghali for managing data collection, and Yena Song for computing the exposure measures and preparing the maps.

\section{Appendix A. Maps of Connect2 intervention}

This appendix contains three maps of the Connect2 intervention sites. 


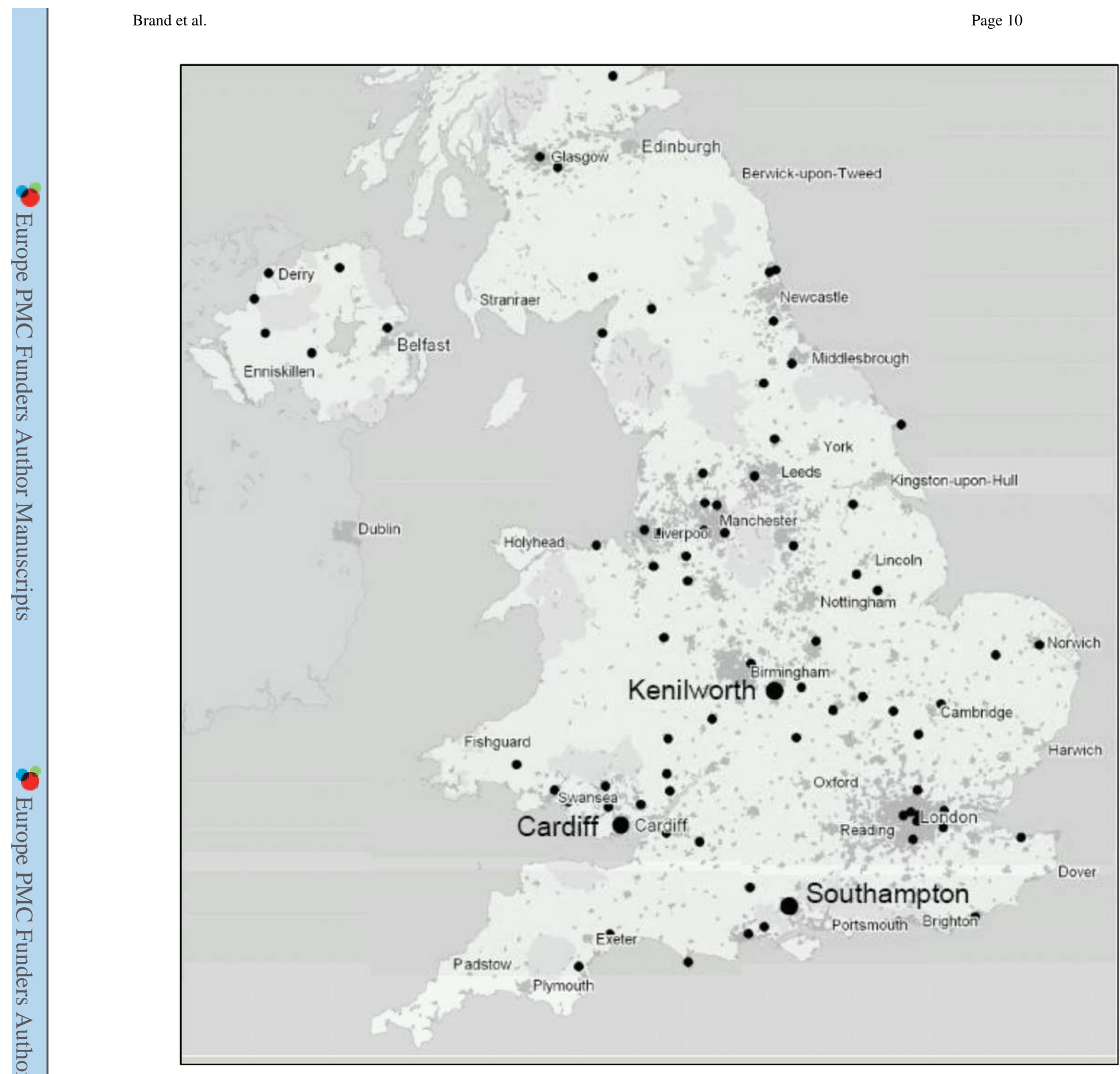

Figure A.1: Locations of UK case study sites

Reproduced with the permission of Sustrans. 


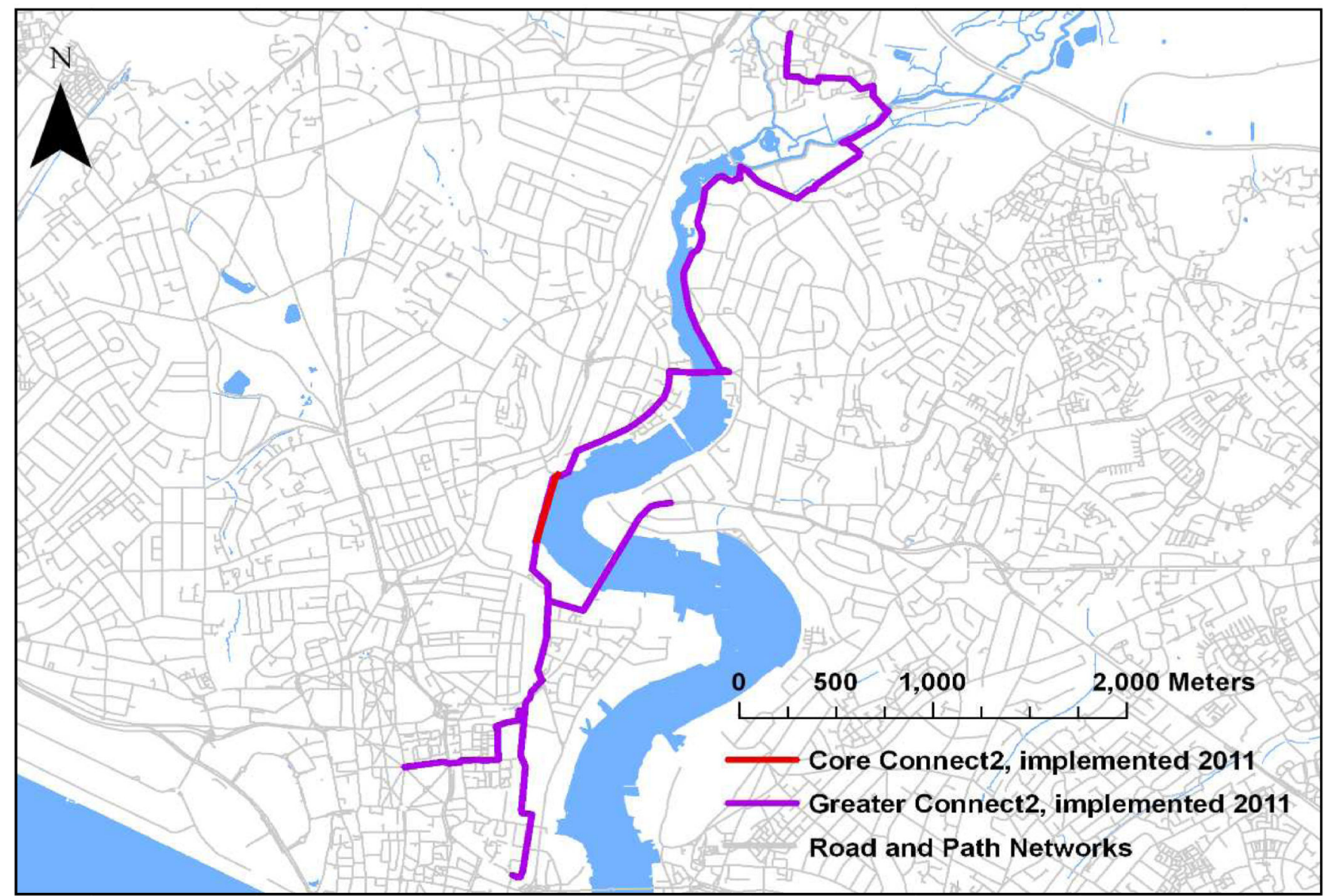

Figure A.2: 'Core' and 'greater' Connect2 projects in the Southampton study site 


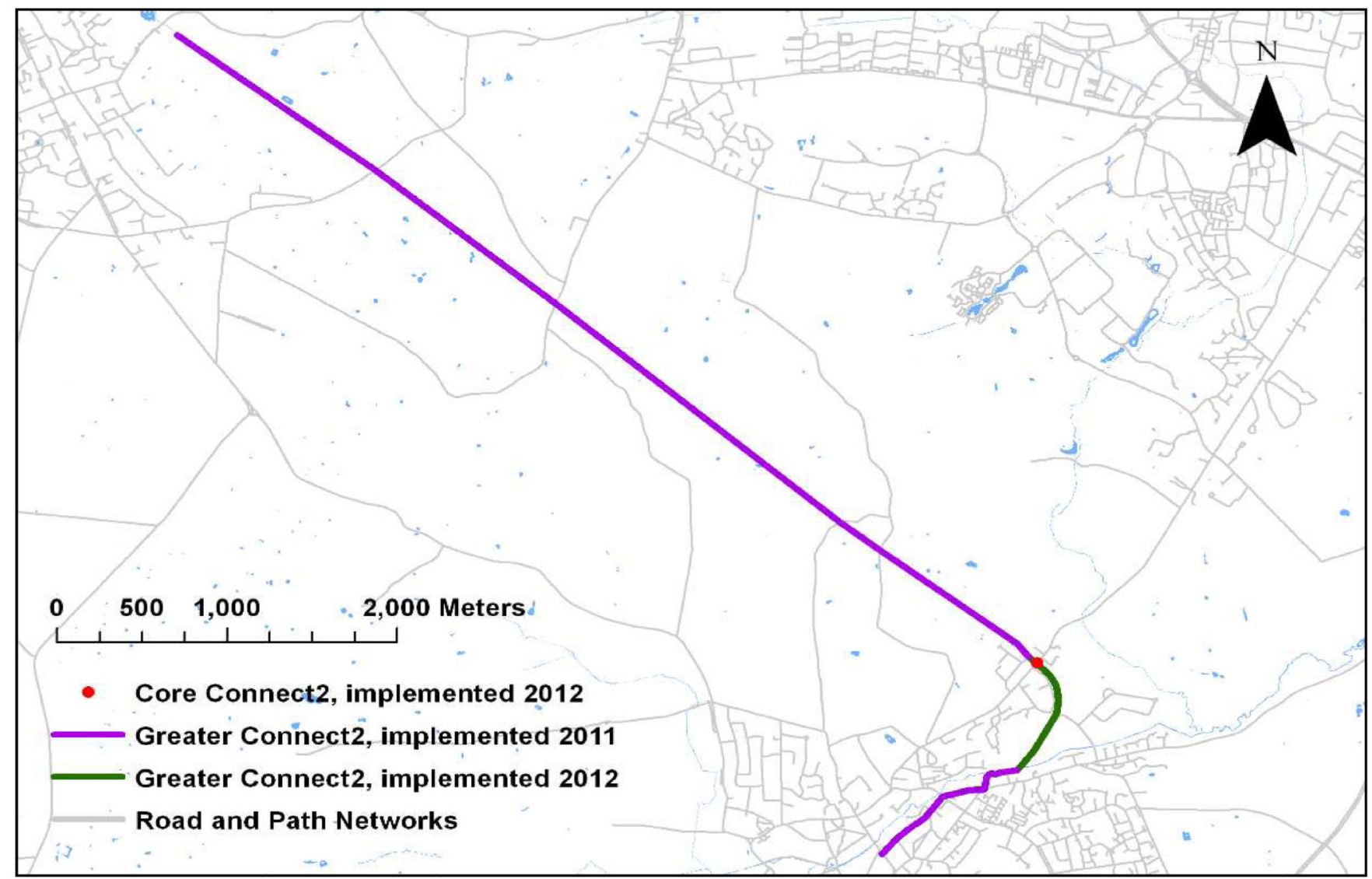

Figure A.3: 'Core' and 'greater' Connect2 projects in the Kenilworth study site

\section{Appendix B. Comparison of study population cohorts versus the general population}

This appendix contains a comparison of the study population versus the general population, including references.

Table B.1:

Comparison of study population versus the general population

\begin{tabular}{|c|c|c|c|c|c|c|}
\hline \multirow[t]{2}{*}{ Domain } & \multirow[t]{2}{*}{$\begin{array}{l}\text { Baseline } \\
\text { characteristics }\end{array}$} & \multirow[t]{2}{*}{ Level } & \multicolumn{2}{|c|}{$\begin{array}{c}\text { Study sample, } \\
\text { weighted by age \& } \\
\text { sex }(\%)\end{array}$} & \multirow[t]{2}{*}{$\begin{array}{c}\begin{array}{c}\text { General } \\
\text { population }\end{array} \\
(\%)\end{array}$} & \multirow[t]{2}{*}{$\begin{array}{l}\text { Comparison } \\
\text { population }\end{array}$} \\
\hline & & & $\begin{array}{l}\text { One year } \\
(\mathrm{N}=1849)\end{array}$ & $\begin{array}{c}\text { Two } \\
\text { year } \\
(\mathbf{N}=\mathbf{1 5 1 0})\end{array}$ & & \\
\hline \multirow[t]{3}{*}{ Demographic } & Sex & Female & 51 & 51 & 51 & \multirow{3}{*}{$\begin{array}{l}{ }^{a} \text { Local: } \\
\text { Office for } \\
\text { National } \\
\text { Statistics } \\
2010\end{array}$} \\
\hline & & Male & 49 & 49 & 49 & \\
\hline & Age (years) & $18-29$ & 26 & 25 & 26 & \\
\hline
\end{tabular}




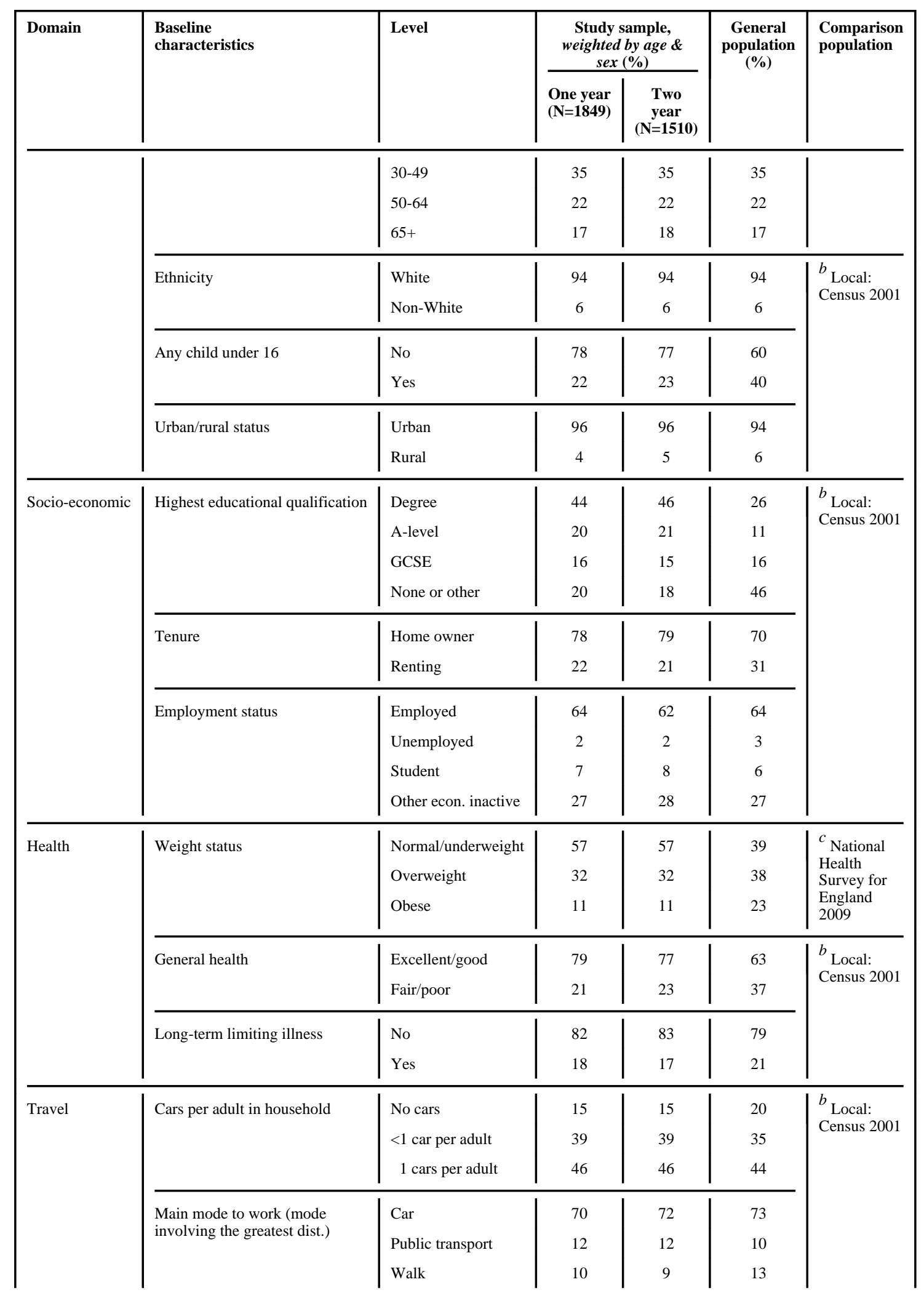




\begin{tabular}{|c|c|c|c|c|c|c|}
\hline \multirow[t]{2}{*}{ Domain } & \multirow[t]{2}{*}{$\begin{array}{l}\text { Baseline } \\
\text { characteristics }\end{array}$} & \multirow[t]{2}{*}{ Level } & \multicolumn{2}{|c|}{$\begin{array}{c}\begin{array}{c}\text { Study sample, } \\
\text { weighted by age \& } \\
\text { sex }(\%)\end{array} \\
\end{array}$} & \multirow[t]{2}{*}{$\begin{array}{c}\text { General } \\
\text { population } \\
(\%)\end{array}$} & \multirow[t]{2}{*}{$\begin{array}{l}\text { Comparison } \\
\text { population }\end{array}$} \\
\hline & & & $\begin{array}{l}\text { One year } \\
(N=1849)\end{array}$ & $\begin{array}{c}\text { Two } \\
\text { year } \\
(\mathbf{N}=1510)\end{array}$ & & \\
\hline & & Cycle & 9 & 7 & 4 & \\
\hline & \multirow{5}{*}{$\begin{array}{l}\text { Percentage travel distance } \\
\text { covered by different modes }\end{array}$} & Car & 75 & 77 & 78 & \multirow{5}{*}{$\begin{array}{l}d_{\text {National: }} \\
\text { National } \\
\text { Travel } \\
\text { Survey, } \\
2010\end{array}$} \\
\hline & & Bus or train & 17 & 15 & 14 & \\
\hline & & Walk & 4 & 4 & 3 & \\
\hline & & Cycle & 2 & 2 & 1 & \\
\hline & & Other modes & 2 & 2 & 4 & \\
\hline
\end{tabular}

\footnotetext{
${ }^{a}$ ONS mid 2010 population estimates (Office for National Statistics 2011), percentages calculated by authors. We included all adult residents (aged $\geq 16$ years) living in the three local authorities from which we drew our study samples, giving equal weighting to each local authority.

${ }^{b}$ Census 2001 5\% sample in Small Area Microdata (Office for National Statistics 2004), percentages calculated by authors. We included all adult residents (aged $>20$ years) living in private households in the three local authorities from which we drew our study samples, giving equal weighting to each local authority. To ensure comparability, we also restricted our study sample to those aged 20 or more ( $97 \%$ of sample) when making comparisons with the census data.

${ }^{c}$ Health Survey for England 2009, adult sample (NHS Information Centre 2010)

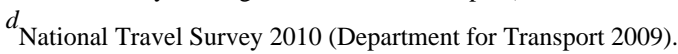

\section{References to Appendix B}

1. Department for Transport. [accessed 14/11/2011] National Travel Survey: Why People Travel. 2009. http://assets.dft.gov.uk/statistics/releases/national-travel-survey-2010/nts2010-03.pdf

2. NHS Information Centre. [accessed 14/11/2011] Health Survey for England 2009: Trend tables. 2010. http://www.ic.nhs.uk/statistics-and-data-collections/health-and-lifestyles-related-surveys/ health-survey-for-england/health-survey-for-england--2009-trend-tables

3. Office for National Statistics. Census 2001 Small Area Microfile. 2004. Available via http:// www.ons.gov.uk/ons/about-ons/who-we-are/services/unpublished-data/census-data/sam/index.html

4. Office for National Statistics. Population Estimates for UK, England and Wales, Scotland and Northern Ireland: Mid-2010 Population Estimates. Office for National Statistics; London: 2011.

\section{Appendix C. Raw levels of and changes in $\mathrm{CO} 2$ emissions}

This appendix shows the distribution of Connect 2 proximity and use at one- and two-year follow-up, and raw levels and changes in outcome variables. It also provides results on weekly $\mathrm{CO}_{2}$ emissions at baseline and one-year follow-up, stratified by Connect 2 exposure. 


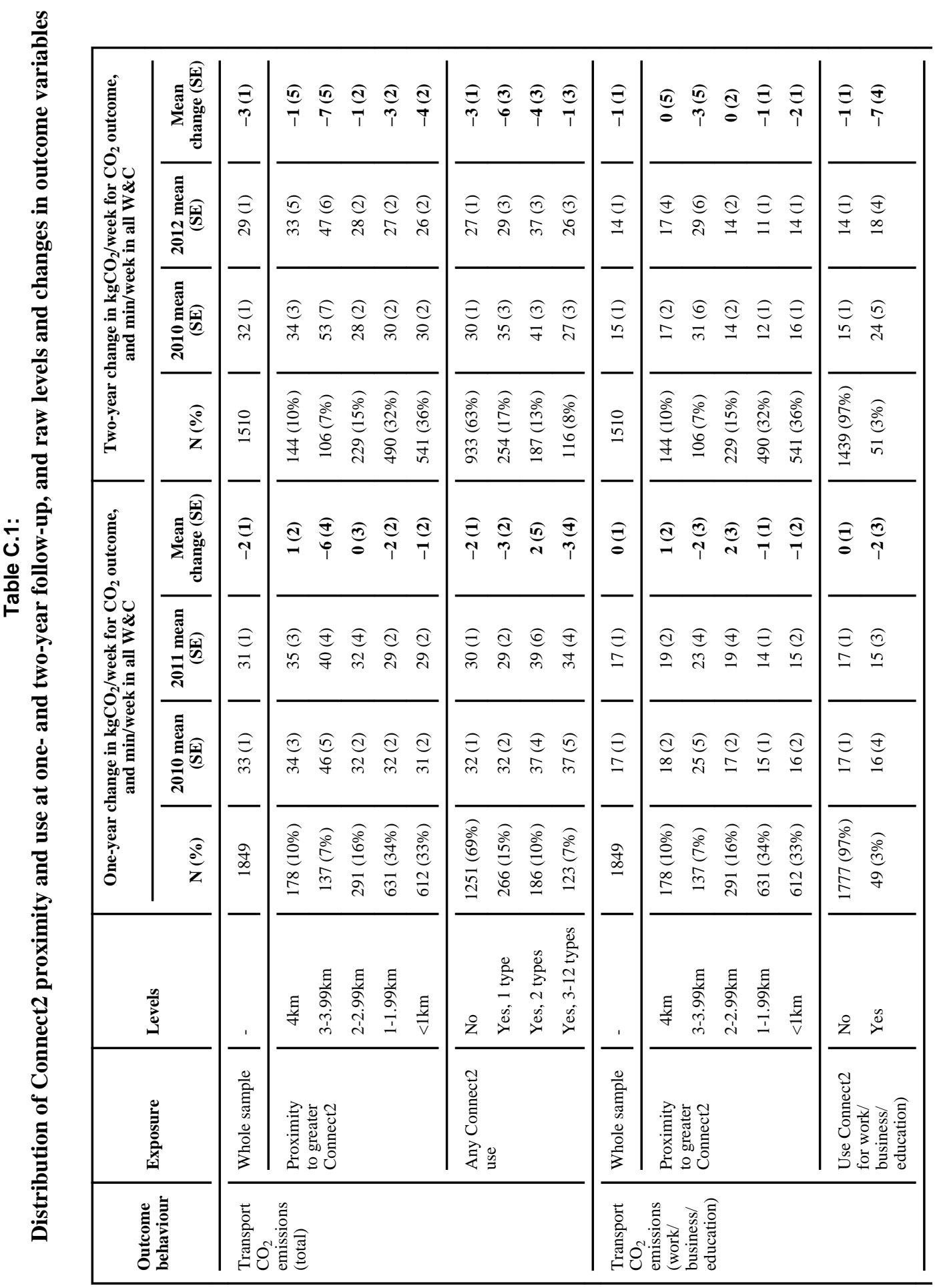




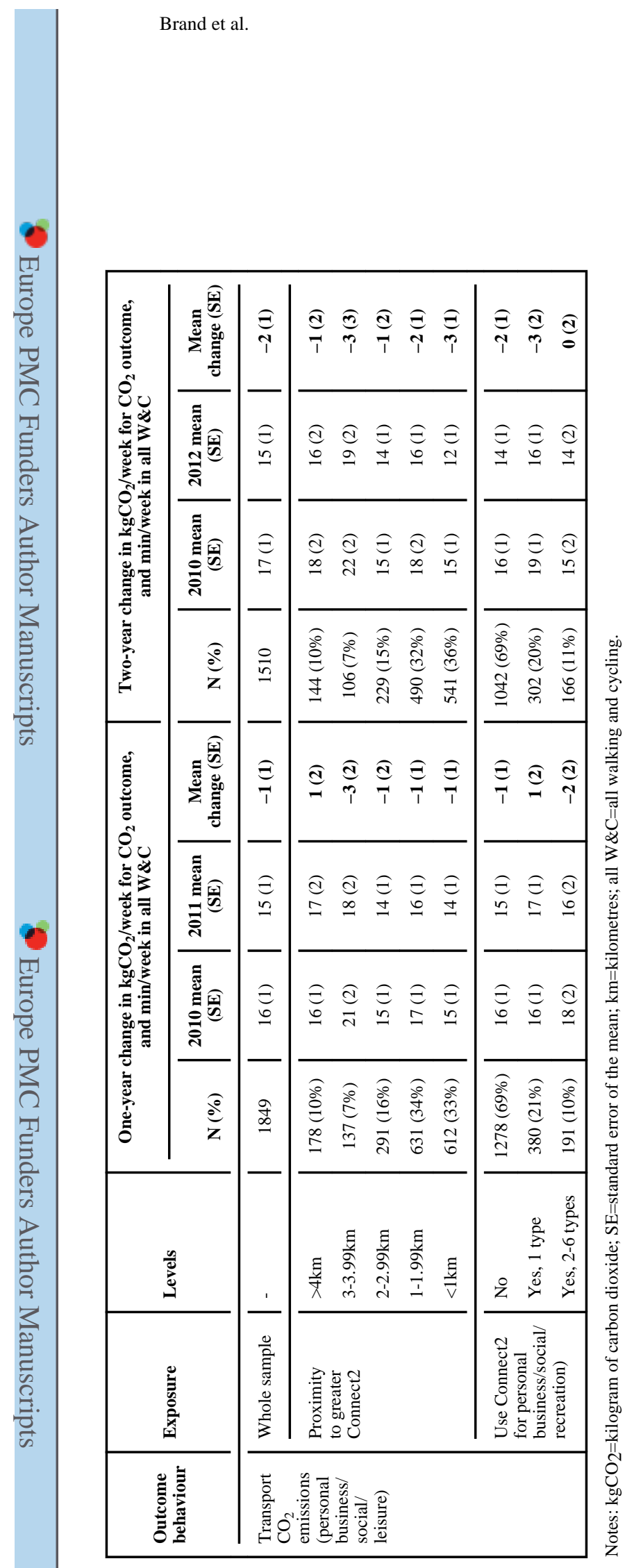

Page 16 


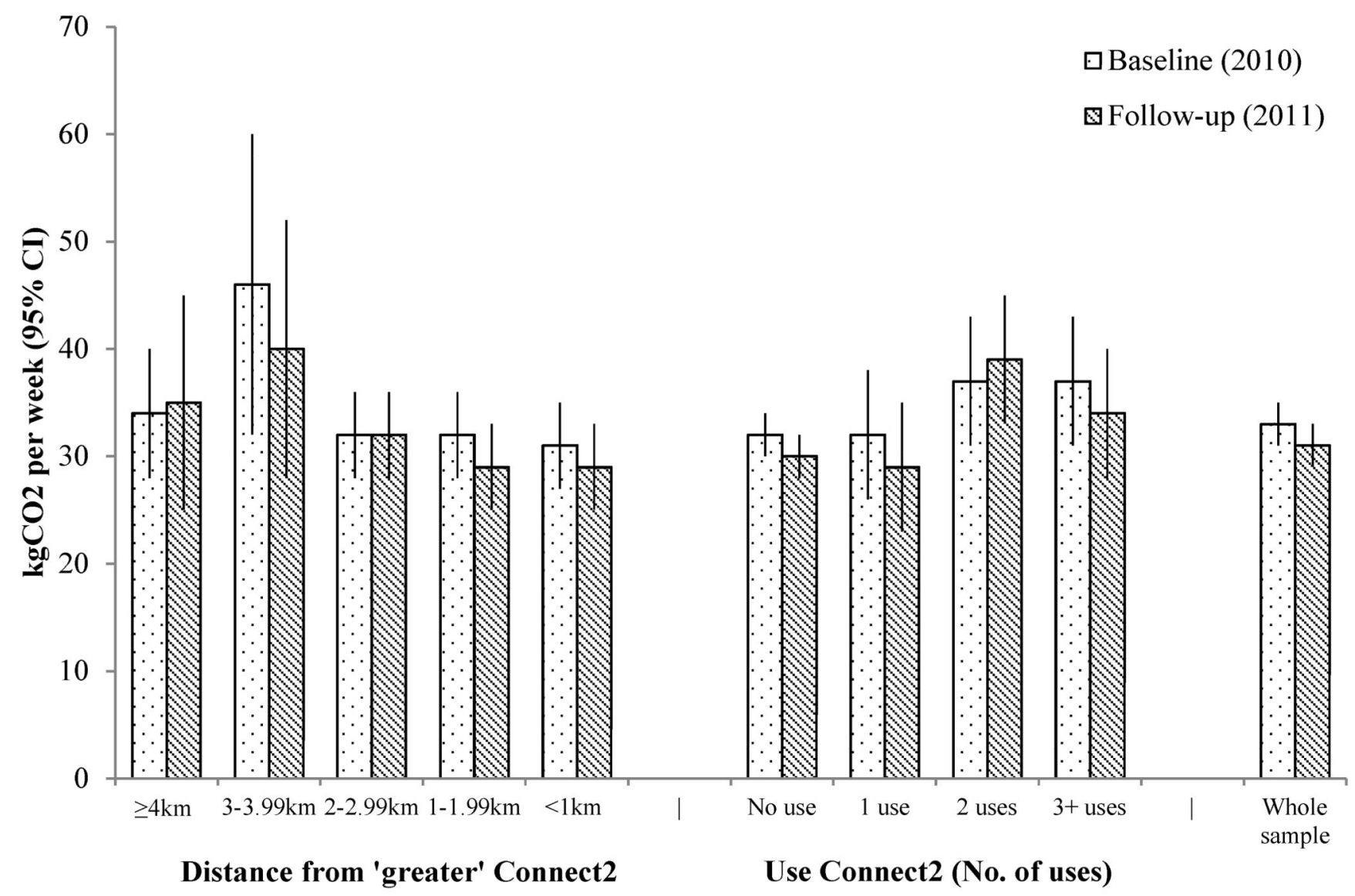

Figure C.1: Weekly $\mathrm{CO}_{2}$ emissions at baseline and one-year follow-up, stratified by Connect2 exposure $(\mathbf{N}=1849)$

\section{Appendix D. Post-hoc power calculations of effectiveness}

This appendix contains a table showing observed data used in post-hoc calculations of our power to detect relative changes in our primary outcome measure in contrasts by a) distance and b) Connect 2 use. It also contains a figure showing post-hoc calculations of our power to detect relative changes in total $\mathrm{CO}_{2}$ emissions in contrasts by a) distance and b) Connect2 use. 
Table D.1:

Observed data used in post-hoc calculations of our power to detect relative changes in our primary outcome measure in contrasts by a) distance and b) Connect 2 use

\begin{tabular}{|c|c|c|c|c|c|c|c|c|}
\hline \multirow{3}{*}{ Outcome } & \multicolumn{4}{|c|}{$\begin{array}{l}\text { SD of change score }\left(\mathrm{kgCO}_{2} / \text { week }\right) \\
\text { One-year follow-up ( } 2010 \text { to } 2011)\end{array}$} & \multicolumn{4}{|c|}{$\begin{array}{l}\text { SD of change score }\left(\mathrm{kgCO}_{2} / \text { week }\right) \\
\text { Two-year follow-up (2010 to 2012) }\end{array}$} \\
\hline & \multicolumn{2}{|c|}{$\begin{array}{l}\text { Distance from } \\
\text { greater Connect2 }\end{array}$} & \multicolumn{2}{|c|}{ Connect2 use } & \multicolumn{2}{|c|}{$\begin{array}{l}\text { Distance from } \\
\text { greater Connect2 }\end{array}$} & \multicolumn{2}{|c|}{ Connect2 use } \\
\hline & $\begin{array}{c}\text { Live } \\
\geq 2 \mathbf{k m} \\
(\mathrm{N}=606)\end{array}$ & $\begin{array}{c}\begin{array}{c}\text { Live } \\
<2 \mathrm{~km} \\
(\mathrm{~N}=1243)\end{array}\end{array}$ & $\begin{array}{l}\text { Non-user } \\
(\mathrm{N}=1240)\end{array}$ & $\begin{array}{c}\text { Users } \\
(\mathbf{N}=586)\end{array}$ & $\begin{array}{c}\text { Live } \\
\geq 2 \mathrm{~km} \\
(\mathrm{~N}=479)\end{array}$ & $\begin{array}{c}\begin{array}{c}\text { Live } \\
<2 \mathrm{~km} \\
(\mathrm{~N}=1031)\end{array}\end{array}$ & $\begin{array}{c}\text { Non-user } \\
(\mathbf{N}=927)\end{array}$ & $\begin{array}{l}\text { Users } \\
(\mathbf{N}=563)\end{array}$ \\
\hline $\begin{array}{l}\text { Transport } \\
\mathrm{CO}_{2} \text {, total }\end{array}$ & 46.5 & 45.0 & 41.5 & 53.0 & 48.7 & 40.3 & 44.2 & 42.0 \\
\hline
\end{tabular}
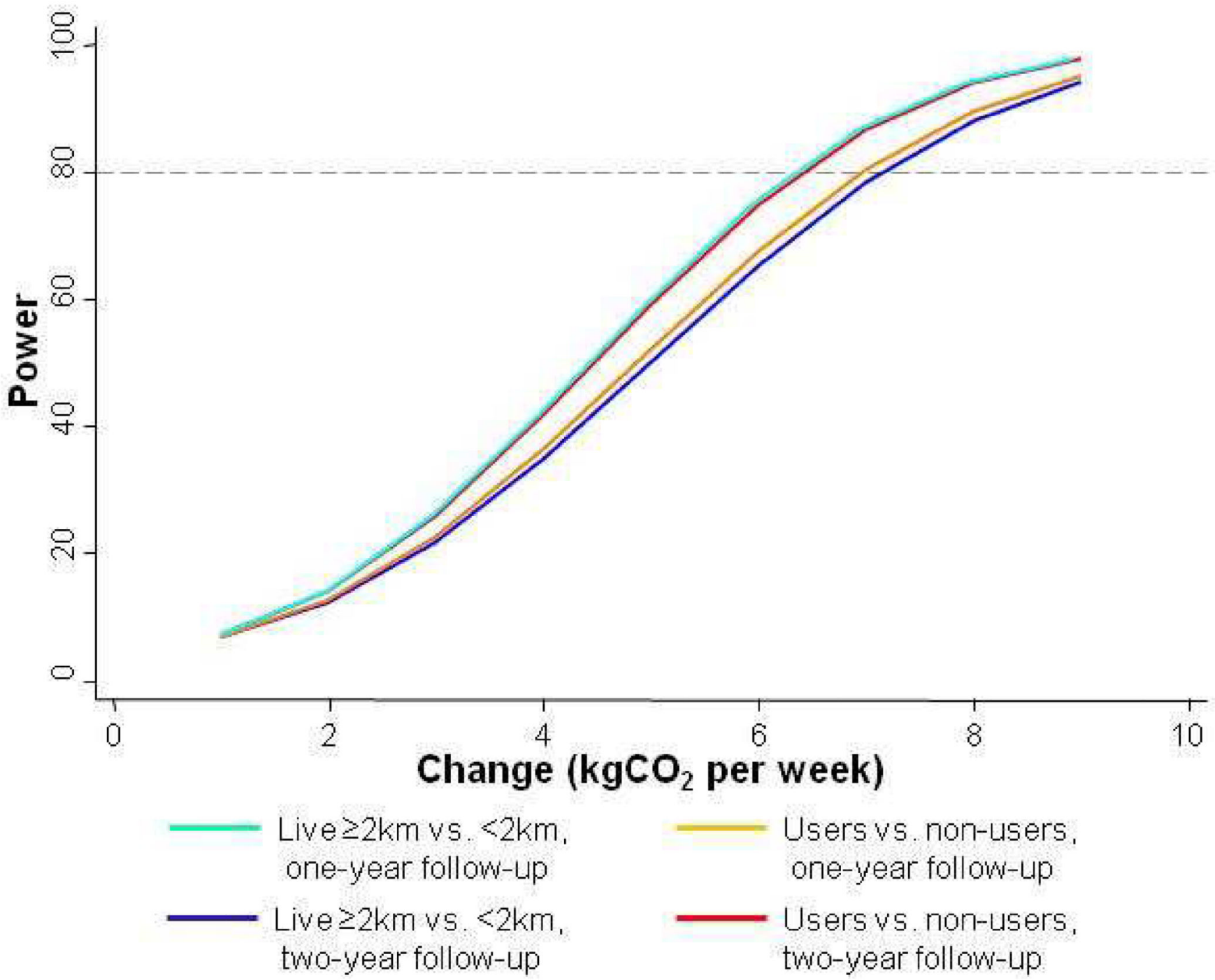

Users vs non-users, one-year follow-up

Users vs non-users, two-year follow-up 
Figure D.1: Post-hoc calculations of our power to detect relative changes in total $\mathrm{CO}_{2}$ emissions in contrasts by a) distance and b) Connect 2 use

\section{GLOSSARY}

$\begin{array}{ll}\text { BMI } & \text { Body Mass Index } \\ \text { CI } & \text { Confidence interval } \\ \mathbf{C O}_{2} & \text { carbon dioxide } \\ \text { UK } & \text { United Kingdom }\end{array}$

\section{REFERENCES}

[1]. Maibach E, Steg L, Anable J. Promoting physical activity and reducing climate change: Opportunities to replace short car trips with active transportation. Prev Med. 2009; 49:326-7. [PubMed: 19591861]

[2]. Lovelace R, Beck SBM, Watson M, Wild A. Assessing the energy implications of replacing car trips with bicycle trips in Sheffield, UK. Energy Policy. 2011; 39:2075-87.

[3]. de Nazelle A, Morton BJ, Jerrett M, Crawford-Brown D. Short trips: An opportunity for reducing mobile-source emissions? Transp Res: Part D: Transport Environ. 2010; 15:451-7.

[4]. Rabl A, de Nazelle A. Benefits of shift from car to active transport. Transport Policy. 2012; 19:121-31.

[5]. Pucher J, Buehler R, Seinen M. Bicycling renaissance in North America? An update and reappraisal of cycling trends and policies. Transp Res: Part A: Pol Practice. 2011; 45:451-75.

[6]. Kahn Ribeiro, S.; Kobayashi, S.; Beuthe, M.; Gasca, J.; Greene, D.; Lee, DS., et al. Transport and its infrastructure. In: Metz, B.; Davidson, OR.; Bosch, PR.; Dave, R.; Meyer, LA., editors. Climate Change 2007: Mitigation Contribution of Working Group III to the Fourth Assessment Report of the Intergovernmental Panel on Climate Change. Cambridge University Press; Cambridge, United Kingdom and New York, NY, USA: 2007.

[7]. Lindfeldt EG, Saxe M, Magnusson M, Mohseni F. Strategies for a road transport system based on renewable resources - The case of an import-independent Sweden in 2025. Appl Energy. 2010; $87: 1836-45$.

[8]. SIKA. The National Travel Survey, RES 2005-2006. Swedish Institute for Transport and Communications Analysis (SIKA); Östersund, Sweden: 2007. report no 2007:19

[9]. DfT. Transport Statistics Great Britain 2013. Department for Transport; London: 2013.

[10]. DfT. Low carbon transport: A greener future. A carbon reduction strategy for transport. Department for Transport; London: 2009.

[11]. Preston, I.; White, V.; Thumim, J.; Bridgeman, T.; Brand, C. Distribution of carbon emissions in the UK: implications for domestic energy policy. Joseph Rowntree Foundation; London: 2013.

[12]. DfT. Creating Growth, Cutting Carbon (Cm 7996). Department for Transport, The Stationery Office; London: 2011.

[13]. ECF. Cycle more Often 2 cool down the planet! - Quantifying CO2 savings of Cycling. European Cyclists' Federation (ECF); Brussels: 2011.

[14]. Goodman A, Brand C, Ogilvie D. Associations of health, physical activity and weight status with motorised travel and transport carbon dioxide emissions: a cross-sectional, observational study. Environ Health. 2012; 11:52. [PubMed: 22862811]

[15]. Ogilvie D, Egan M, Hamilton V, Petticrew M. Promoting walking and cycling as an alternative to using cars: systematic review. BMJ. 2004; 329:763. [PubMed: 15385407]

[16]. Sælensminde K. Cost-benefit analyses of walking and cycling track networks taking into account insecurity, health effects and external costs of motorized traffic. Transp Res: Part A: Pol Practice. 2004; 38:593-606. 
[17]. Brand C, Goodman A, Rutter H, Song Y, Ogilvie D. Associations of individual, household and environmental characteristics with carbon dioxide emissions from motorised passenger travel. Appl Energy. 2013; 104:158-69. [PubMed: 24882922]

[18]. Frank LD, Greenwald MJ, Winkelman S, Chapman J, Kavage S. Carbonless footprints: promoting health and climate stabilization through active transportation. Prev Med. 2010; 50(Suppl 1):S99-105. [PubMed: 19850071]

[19]. Frank LD, Saelens BE, Powell KE, Chapman JE. Stepping towards causation: do built environments or neighborhood and travel preferences explain physical activity, driving, and obesity? Soc Sci Med. 2007; 65:1898-914. [PubMed: 17644231]

[20]. Haines A, McMichael AJ, Smith KR, Roberts I, Woodcock J, Markandya A, et al. Public health benefits of strategies to reduce greenhouse-gas emissions: overview and implications for policy makers. Lancet. 2009; 374:2104-14. [PubMed: 19942281]

[21]. Woodcock J, Edwards P, Tonne C, Armstrong BG, Ashiru O, Banister D, et al. Public health benefits of strategies to reduce greenhouse-gas emissions: urban land transport. Lancet. 2009; 374:1930-43. [PubMed: 19942277]

[22]. Giles-Corti B. People or places: what should be the target? J Sci Med Sport. 2006; 9:357-66. [PubMed: 16931155]

[23]. McCormack GR, Shiell A. In search of causality: a systematic review of the relationship between the built environment and physical activity among adults. Int J Behav Nutr Phys Act. 2011; 8:125. [PubMed: 22077952]

[24]. NICE. Promoting and creating built or natural environments that encourage and support physical activity (NICE Public Health Guidance 8). National Institute for Health and Clinical Excellence (NICE); London: 2008.

[25]. Krizek KJ, Handy SL, Forsyth A. Explaining changes in walking and bicycling behavior: challenges for transportation research. Environ Plann B. 2009; 36:725-40.

[26]. Pucher J, Dill J, Handy S. Infrastructure, programs, and policies to increase bicycling: An international review. Prev Med. 2010; 50:S106-S25. [PubMed: 19765610]

[27]. Yang L, Sahlqvist S, McMinn A, Griffin SJ, Ogilvie D. Interventions to promote cycling: systematic review. BMJ. 2010; 341:c5293. [PubMed: 20959282]

[28]. Goodman A, Sahlqvist S, Ogilvie D. Who uses new walking and cycling infrastructure and how? Longitudinal results from the UK iConnect study. Prev Med. 2013; 57:518-24. [PubMed: 23859933]

[29]. Goodman A, Sahlqvist S, Ogilvie D. Do new walking and cycling routes increase physical activity? One- and two-year findings from the UK iConnect study. Am J Public Health. in press.

[30]. Sustrans. [Accessed 8th August 2012] Connect2: Enabling millions of people to make everyday, local journeys by foot or by bike. 2012. http://www.sustrans.org.uk/what-we-do/connect2

[31]. Ogilvie D, Bull F, Cooper A, Rutter H, Adams E, Brand C, et al. Evaluating the travel, physical activity and carbon impacts of a 'natural experiment' in the provision of new walking and cycling infrastructure: methods for the core module of the iConnect study. BMJ Open. 2012; 2:e000694.

[32]. Ogilvie D, Bull F, Powell J, Cooper AR, Brand C, Mutrie N, et al. An applied ecological framework for evaluating infrastructure to promote walking and cycling: the iConnect study. Am J Public Health. 2011; 101:473-81. [PubMed: 21233429]

[33]. EPA. Climate Leaders Greenhouse Gas Inventory Protocol: Direct Emissions from Mobile Combustion Sources. United States Environmental Protection Agency; 2008. Report EPA430K-08-004

[34]. Defra. 2010 Guidelines to Defra / DECC's GHG Conversion Factors for Company Reporting. Defra; London: 2010.

[35]. Craig CL, Marshall AL, Sjostrom M, Bauman AE, Booth ML, Ainsworth BE, et al. International physical activity questionnaire: 12-country reliability and validity. Med Sci Sports Exerc. 2003; 35:1381-95. [PubMed: 12900694]

[36]. ONS. Lower Super Output Area Population Estimates - Mid-2010. Office for National Statistics; 2011. http://www.ons.gov.uk/ons/rel/sape/soa-mid-year-pop-est-engl-wales-exp/mid-2010release/rft---mid-2010-1soa-population-estimates.zip [last accessed 13/11/2011] 
[37]. ONS. Census 2011. Office of National Statistics; London: 2013. http://www.ons.gov.uk/ons/ guide-method/census/2011/census-data/index.html [Data last accessed 25/11/2013]

[38]. AEA Technology. Local and Regional CO2 Emissions Estimates for 2005-2008. AEA Technology; Harwell: 2010. Report to Department for Energy and Climate Change, ED 56403105

[39]. DfT. Transport Statistics Great Britain: 2010 edition. Department for Transport (DfT), The Stationary Office; London: 2010.

[40]. DECC. Sub-national road transport fuel consumption statistics 2011 (URN: 13D/108). Department of Energy \& Climate Change; London: 2013.

[41]. DECC. Local Authority CO2 emissions estimates 2011: Statistical Summary and UK Maps. Department of Energy \& Climate Change; London: 2013.

[42]. Dargay J. The effect of prices and income on car travel in the UK. Transp Res: Part A: Pol Practice. 2007; 41:949-60.

[43]. SMMT. New Car $\mathrm{CO}_{2}$ Report 2013: The 12th report. The Society of Motor Manufacturers and Traders (SMMT); London: 2013.

[44]. Wilmink, A.; Hartman, J. Evaluation of the Delft bicycle network plan: final summary report. Ministry of Transport and Public Works; Netherlands: 1987.

[45]. Troelsen, J.; Jensen, S.; Andersen, T. Evaluering af Odense-Danmarks nationale cykelby [Evaluation of Odense-Denmark's national cycle city] [Danish]. Odense Kommune; 2004.

[46]. Sloman, L.; Cavill, N.; Cope, A.; Muller, L.; Kennedy, A. Analysis and synthesis of evidence on the effects of investment in six cycling demonstration towns. Department for Transport and Cycling; England: 2009.

[47]. Fitzhugh EC, Bassett DR Jr. Evans MF. Urban trails and physical activity: a natural experiment. Am J Prev Med. 2010; 39:259-62. [PubMed: 20709258]

[48]. Brown WJ, Mummery K, Eakin E, Schofield G. 10,000 Steps Rockhampton: Evaluation of a whole community approach to improving population levels of physical activity. J Phys Act Health. 2006; 1:1-14. 


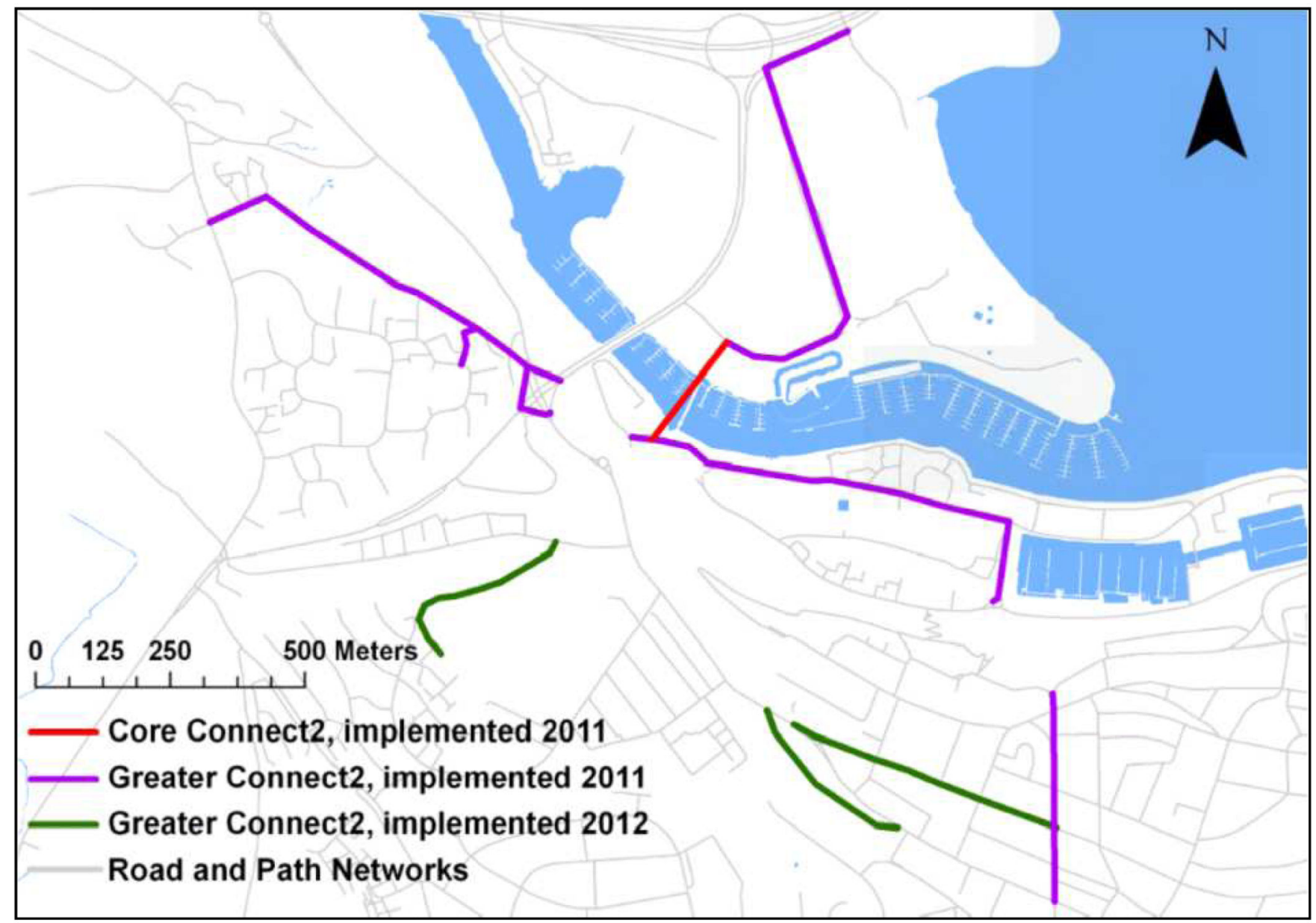

Figure 1. 'Core' and 'greater' Connect2 projects in the Cardiff study site Purple lines show the sections of the greater Connect 2 network which were operational at the time of both the 2011 and the 2012 surveys; green lines show the sections of the network only operational at the time of the 2012 survey. Map contains Ordnance Survey data () Crown copyright and database right 2011. See Appendices for equivalent maps of Southampton and Kenilworth, and for the locations of these three study sites. 


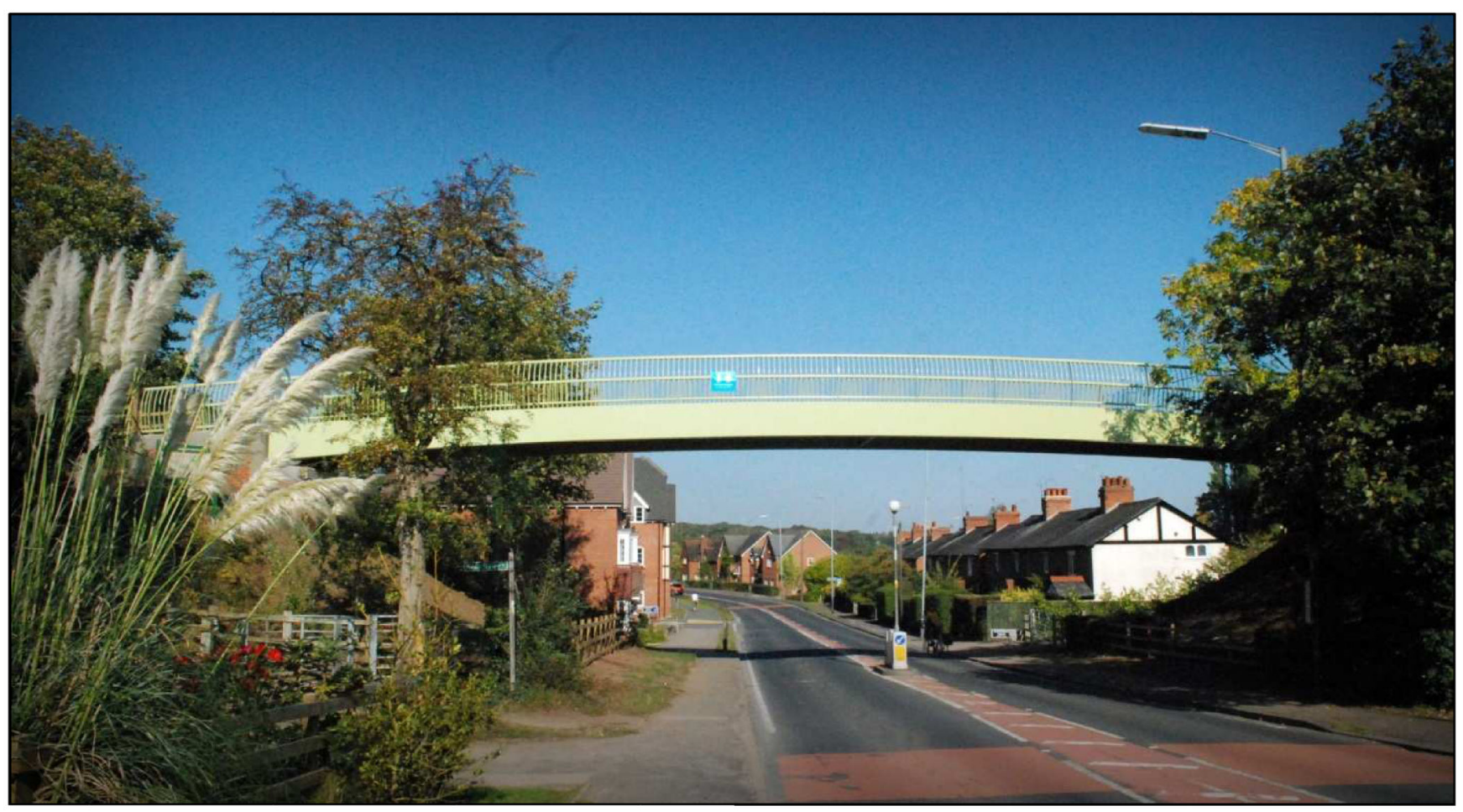

Figure 2. Illustration of the 'core' (flagship) element of the Kenilworth Connect2 scheme, a walking and cycling bridge

Reproduced with the permission of Andre Neves (C) 2012 


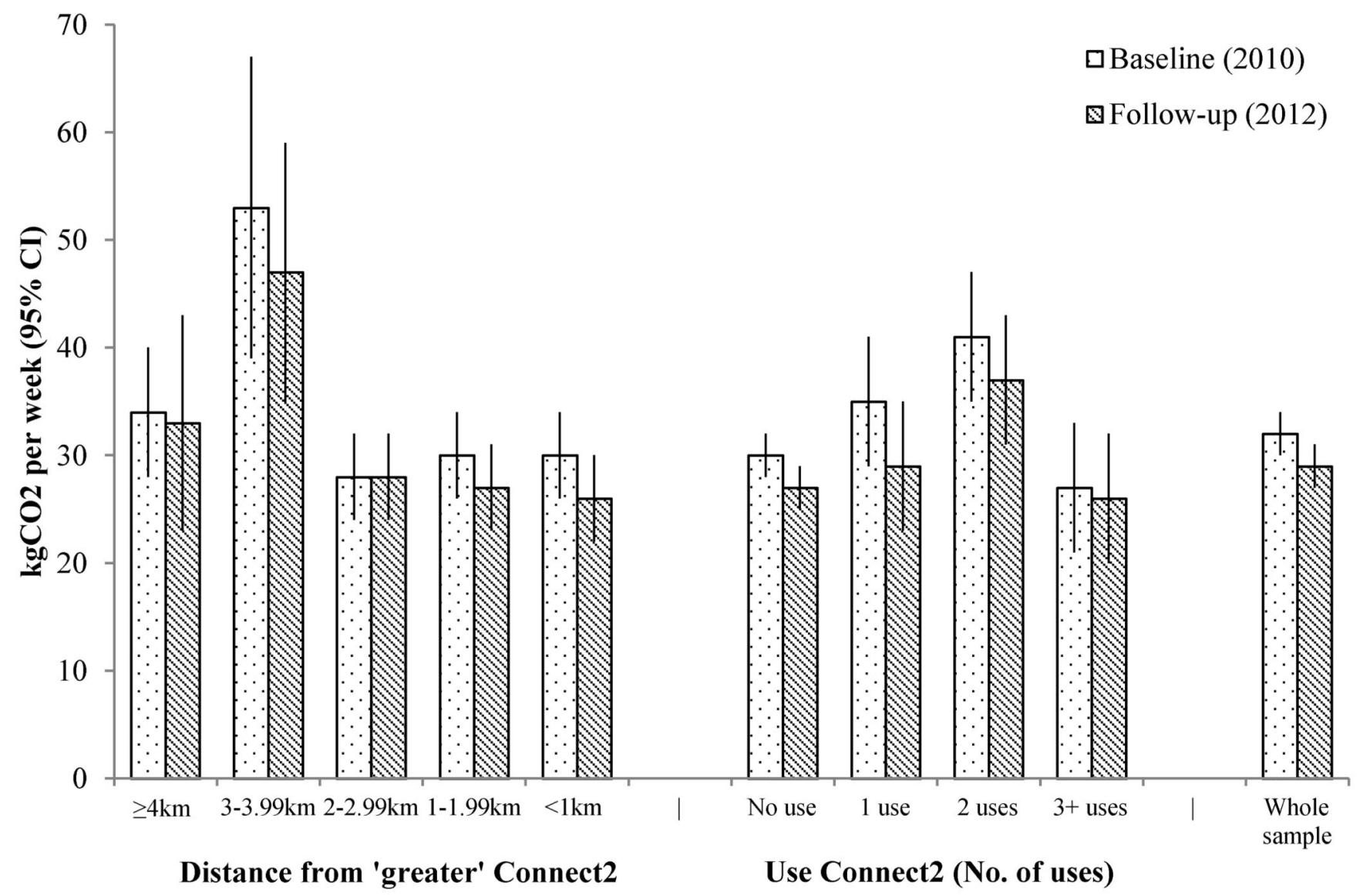

Figure 3. Weekly $\mathrm{CO}_{2}$ emissions at baseline and two-year follow-up, stratified by Connect2 exposure $(\mathrm{N}=1510)$ 
Table 1

Study participants' characteristics at baseline ${ }^{\dagger}$

\begin{tabular}{|c|c|c|c|c|}
\hline Domain & Variable & Level & $\begin{array}{l}\mathrm{N}(\%) \text { in 1-year } \\
\text { sample }\end{array}$ & $\begin{array}{l}\mathrm{N}(\%) \text { in 2-year } \\
\text { sample }\end{array}$ \\
\hline \multirow[t]{8}{*}{ Geographic } & \multirow[t]{3}{*}{ Site } & Southampton & $523(28 \%)$ & $425(28 \%)$ \\
\hline & & Cardiff & $596(32 \%)$ & $487(32 \%)$ \\
\hline & & Kenilworth & $730(39 \%)$ & $598(40 \%)$ \\
\hline & \multirow[t]{5}{*}{ Proximity of home to greater Connect2 (km) } & $\geq 4$ & $178(10 \%)$ & $144(10 \%)$ \\
\hline & & 3-3.99 & $137(7 \%)$ & $106(7 \%)$ \\
\hline & & $2-2.99$ & $291(16 \%)$ & $229(15 \%)$ \\
\hline & & $1-1.99$ & $631(34 \%)$ & $490(33 \%)$ \\
\hline & & $<1$ & $612(33 \%)$ & $541(36 \%)$ \\
\hline \multirow[t]{10}{*}{ Demographic } & \multirow[t]{2}{*}{ Sex } & Female & $1006(54 \%)$ & $857(57 \%)$ \\
\hline & & Male & $843(46 \%)$ & $653(43 \%)$ \\
\hline & \multirow[t]{4}{*}{ Age (years) at baseline } & $18-34$ & $241(13 \%)$ & $144(10 \%)$ \\
\hline & & $35-49$ & $379(21 \%)$ & $300(20 \%)$ \\
\hline & & $50-64$ & $607(33 \%)$ & $532(35 \%)$ \\
\hline & & $65-89$ & $616(33 \%)$ & $530(35 \%)$ \\
\hline & \multirow[t]{2}{*}{ Ethnicity } & White & $1771(97 \%)$ & $1460(97 \%)$ \\
\hline & & Non-White & $64(3 \%)$ & $45(3 \%)$ \\
\hline & \multirow[t]{2}{*}{ Any child under 16} & No & $1547(84 \%)$ & $1276(85 \%)$ \\
\hline & & Yes & $301(16 \%)$ & $234(16 \%)$ \\
\hline \multirow[t]{10}{*}{ Socio-economic status } & \multirow[t]{3}{*}{ Highest educational level } & Tertiary or equivalent & $715(39 \%)$ & $590(39 \%)$ \\
\hline & & Secondary school ${ }^{\dagger}$ & $619(34 \%)$ & $490(33 \%)$ \\
\hline & & None or other & $495(27 \%)$ & $425(28 \%)$ \\
\hline & \multirow[t]{3}{*}{ Annual household income } & $>£ 40,000$ & $582(34 \%)$ & $451(32 \%)$ \\
\hline & & $£ 20,001-40,000$ & $543(32 \%)$ & $469(33 \%)$ \\
\hline & & $\Varangle 20,000$ & $565(33 \%)$ & $488(35 \%)$ \\
\hline & \multirow[t]{4}{*}{ Employment status } & Working & $938(51 \%)$ & $740(49 \%)$ \\
\hline & & Student & $48(3 \%)$ & $25(2 \%)$ \\
\hline & & Retired & $704(38 \%)$ & $609(40 \%)$ \\
\hline & & Other & $152(8 \%)$ & $134(9 \%)$ \\
\hline \multirow[t]{4}{*}{ Car and bicycle access } & \multirow[t]{2}{*}{ Any car in household } & No & $247(13 \%)$ & $215(14 \%)$ \\
\hline & & Yes & $1599(87 \%)$ & $1290(86 \%)$ \\
\hline & \multirow[t]{2}{*}{ Any adult bicycle in household } & No & $768(45 \%)$ & $620(45 \%)$ \\
\hline & & Yes & $948(55 \%)$ & $768(55 \%)$ \\
\hline
\end{tabular}




\begin{tabular}{|c|c|c|c|c|}
\hline Domain & Variable & Level & $\begin{array}{l}\mathbf{N}(\%) \text { in 1-year } \\
\text { sample }\end{array}$ & $\begin{array}{l}\mathbf{N}(\%) \text { in 2-year } \\
\text { sample }\end{array}$ \\
\hline \multirow[t]{3}{*}{ Health } & Weight status & $\begin{array}{l}\text { Normal/underweight } \\
\text { Overweight } \\
\text { Obese }\end{array}$ & $\begin{array}{l}879(50 \%) \\
633(36 \%) \\
244(14 \%)\end{array}$ & $\begin{array}{l}702(49 \%) \\
534(37 \%) \\
201(14 \%)\end{array}$ \\
\hline & General health & $\begin{array}{l}\text { Excellent/good } \\
\text { Fair/poor }\end{array}$ & $\begin{array}{l}1437(79 \%) \\
388(21 \%)\end{array}$ & $\begin{array}{l}1168(78 \%) \\
324(22 \%)\end{array}$ \\
\hline & $\begin{array}{l}\text { Long-term illness or disability that limits } \\
\text { daily activities }\end{array}$ & $\begin{array}{l}\text { No } \\
\text { Yes }\end{array}$ & $\begin{array}{l}1295(75 \%) \\
441(25 \%)\end{array}$ & $\begin{array}{l}1046(74 \%) \\
374(26 \%)\end{array}$ \\
\hline
\end{tabular}

Notes: km=kilometres.

${ }^{\dagger}$ 'A' Levels, GCSEs or equivalent. Results based on 1849 British adults participating in 2010 and 2011, and 1510 participating in 2010 and 2012 : numbers add to less than the total sample size for some variables due to missing data. 
Table 2

Impact of various measures of Connect 2 exposure upon one- and two-year change in total $\mathrm{CO}_{2}$ emissions

\begin{tabular}{|c|c|c|c|c|c|c|c|}
\hline \multirow[t]{2}{*}{$\begin{array}{l}\text { Outcome } \\
\text { behaviour }\end{array}$} & \multirow[t]{2}{*}{ Exposure } & \multicolumn{3}{|c|}{$\begin{array}{l}\text { One-year change, from } 2010 \text { to } 2011 \text { : } \\
\text { unstandardised regression coefficients } \\
(95 \% \mathrm{CI})\end{array}$} & \multicolumn{3}{|c|}{$\begin{array}{l}\text { Two-year change, from } 2010 \text { to } 2012 \text { : } \\
\text { unstandardised regression coefficients } \\
(95 \% \mathrm{CI})\end{array}$} \\
\hline & & $\begin{array}{l}\text { Minimally- } \\
\text { adjusted for sex, } \\
\text { age \& site }\end{array}$ & $\begin{array}{l}\text { Adjusted for } \\
\text { baseline } \\
\text { characteristics }\end{array}$ & $\begin{array}{l}\text { Sensitivity } \\
\text { analysis } \\
\text { (adjusted, } \\
\text { excluding } \\
\text { outliers) }\end{array}$ & $\begin{array}{l}\text { Minimally- } \\
\text { adjusted for sex, } \\
\text { age \& site }\end{array}$ & $\begin{array}{l}\text { Adjusted for } \\
\text { baseline } \\
\text { characteristics }\end{array}$ & $\begin{array}{l}\text { Sensitivity } \\
\text { analysis } \\
\text { (adjusted, } \\
\text { excluding } \\
\text { outliers) }\end{array}$ \\
\hline \multirow[t]{2}{*}{$\begin{array}{l}\text { Total } \\
\text { transport } \\
\mathrm{CO}_{2} \\
\text { emissions }\end{array}$} & $\begin{array}{l}\text { Change } \\
\text { per km } \\
\text { closer to } \\
\text { greater } \\
\text { Connect2 }\end{array}$ & $0.03(-1.80,1.86)$ & $-0.08(-1.93,1.77)$ & $0.39(-0.59,1.38)$ & $-0.81(-2.67,1.04)$ & $-0.75(-2.59,1.09)$ & $0.39(-0.63,1.41)$ \\
\hline & $\begin{array}{l}\text { Use } \\
\text { Connect } 2 \\
\text { for any } \\
\text { purpose } \\
\text { (yes vs. } \\
\text { no) }\end{array}$ & $-1.60(-8.60,5.40)$ & $-2.39(-9.40,4.62)$ & $1.21(-2.61,5.04)$ & $0.36(-6.23,6.96)$ & $0.37(-6.20,6.94)$ & $-1.32(-6.37,3.73)$ \\
\hline \multirow[t]{2}{*}{$\begin{array}{l}\text { Transport } \\
\mathrm{CO}_{2} \\
\text { emissions } \\
\text { (work/ } \\
\text { business/ } \\
\text { education) }\end{array}$} & $\begin{array}{l}\text { Change } \\
\text { per km } \\
\text { closer to } \\
\text { greater } \\
\text { Connect } 2\end{array}$ & $-0.04(-1.62,1.54)$ & $-0.10(-1.67,1.46)$ & $0.01(-0.75,0.76)$ & $-0.47(-2.16,1.22)$ & $-0.48(-2.15,1.18)$ & $0.03(-0.84,0.91)$ \\
\hline & $\begin{array}{l}\text { Use } \\
\text { Connect2 } \\
\text { for work/ } \\
\text { business/ } \\
\text { education } \\
\text { (yes vs. } \\
\text { no) }\end{array}$ & $-1.03(-9.18,7.11)$ & $-0.78(-8.04,6.49)$ & $-0.25(-6.37,5.87)$ & $-6.35(-14.9,2.22)$ & $-5.30(-14.1,3.44)$ & $-7.07(-14.4,0.27)$ \\
\hline \multirow{2}{*}{$\begin{array}{l}\text { Transport } \\
\mathrm{CO}_{2} \\
\text { emissions } \\
\text { (personal/ } \\
\text { business/ } \\
\text { social/ } \\
\text { leisure) }\end{array}$} & $\begin{array}{l}\text { Change } \\
\text { per km } \\
\text { closer to } \\
\text { greater } \\
\text { Connect } 2\end{array}$ & $-0.14(-0.96,0.68)$ & $-0.19(-1.01,0.64)$ & $0.13(-0.55,0.81)$ & $-0.54(-1.69,0.61)$ & $-0.47(-1.60,0.66)$ & $0.26(-0.59,1.11)$ \\
\hline & $\begin{array}{l}\text { Use } \\
\text { Connect2 } \\
\text { for } \\
\text { personal } \\
\text { business/ } \\
\text { social/ } \\
\text { recreation } \\
\text { (yes vs. } \\
\text { no) }\end{array}$ & $1.74(-1.33,4.81)$ & $1.54(-1.52,4.61)$ & $-0.46(-2.74,1.82)$ & $-0.46(-3.29,2.36)$ & $-0.01(-3.08,3.06)$ & $-0.91(-3.49,1.67)$ \\
\hline
\end{tabular}

P-values for linear trend if continuous variables and for heterogeneity if categorical. CI, confidence interval; km, kilometres. Adjusted analyses adjust for baseline demographic, socio-economic, car/bike access and health characteristics (categorised as in Table 1). Adjusted sensitivity analyses are the same as the adjusted analyses except that we excluded those participants whose $\mathrm{CO}_{2}$ emissions changed by more than $100 \mathrm{~kg} /$ week. Note that proximity is distance reverse scored, such that a positive association means a larger increase among those living close to Connect 2 . Binary use variables presented, as there was never evidence of heterogeneity among the different levels of $\geq 1$ use.

${ }^{\dagger} \mathrm{p}<0.1$, from linear regression analyses predicting change in $\mathrm{CO}_{2}$ emissions.

p $<0.05$, from linear regression analyses predicting change in $\mathrm{CO}_{2}$ emissions.

** $\mathrm{p}<0.01$, from linear regression analyses predicting change in $\mathrm{CO}_{2}$ emissions. 